\title{
Identifying the Target Needs of Preparatory Classes for UndergraduatePrograms in Foreign Languages: A Case Study of the Engineering Departments*
}

\author{
Recep Kahramanoglu ${ }^{1}$, Emre Aslan ${ }^{1}$, Islim Derya Yilmaz ${ }^{1}$, Ceyla Odabas ${ }^{1}$, Suleyman Tekerek ${ }^{1}$, Okkes Oflaz $^{1}$ \\ ${ }^{1}$ Gaziantep University, Faculty of Education, Turkey \\ Correspondence: Emre Aslan, Gaziantep University, Faculty of Education, Turkey.
}

Received: October 9, 2018

doi:10.11114/jets.v7i2.3676
Accepted: December 13, $2018 \quad$ Online Published: December 17, 2018

URL: https://doi.org/10.11114/jets.v7i2.3676

\begin{abstract}
The aim of this study is to identify the target needs of preparatory classes for undergraduate programs which teach in foreign languages, in English. The differences between the target needs and the current level of the students constitute the subject of this study. The discrepancy model has been used as the need identification approach. In the discrepancy model, firstly the needs are identified, and then the deficiencies and current level are found. The study was formed in the qualitative research model and nineteen lecturers were included in the study to identify the needs of the study group. At the deficiencies and current level identification stage, the study group consisted of twenty three engineering students who has passed the preparatory class and are having the field courses. Furthermore, thirty two preparatory lecturers were also included in the study group to ascertain the current level. A structured interview form and a questionnaire were used as data collection tools. Data collected through interviews was analyzed with the content analysis method. Mean and standard deviation values were calculated in the analysis of the collected data. According to the study results, the students are equipped with general English skills in preparatory classes. It was also found that the students were given general English classes throughout the year, they focused on grammar and that students were provided with general speaking and writing skills for general subjects at a basic level. However, according to the views of students and lecturers who teaches in field courses, the gainings of preparatory English classes are not sufficient for the field courses. Students and lecturers are of the opinion that problems arise in the understanding and presentation of technical texts in English.
\end{abstract}

Keywords: need analysis, target needs, foreign language education, engineering departments

\section{Introduction}

In this century, it is an undeniable fact that there is a requirement to reach a certain socio-economic, cultural and scientific development level in order to keep up with the growing and transforming global system. Along with the political, economic, scientific and technologic breakthroughs of the 21 st century, we live in an age in which countries and people cannot survive without mutual communication.

Great changes have occurred in the fields of sociology, economics, trade and industry worldwide since the end of World War II. During such a period of development, huge improvements emerged in technology under the effect of industrial production related to trade and scientific developments. These improvements caused the emergence of a new form of communication between countries. The English language spread as a universal language in parallel with the USA's transformation into a leading world power in political and economic terms. The number of people who knew and spoke this language increased worldwide rapidly (Hutchinson and Waters, 1991, p.6).

This development gained more momentum with the oil shock in the international market during the 1970s, the establishment of the OPEC, the rapid increase in oil prices, and accordingly, the transformation of Western states into oil-rich countries, as well as the further rise of the relations between oil-rich countries and Western states, including, predominantly, the USA (Hutchinson and Waters, 1991, p.7).

\footnotetext{
* This study was presented as an oral presentation in IVth International Symposium on Educational and Social Sciences in Turkish Cultural Geograpy, in June 27-30, 2018.
} 
Correspondingly, English language teaching has spread along with the expansion and popularity of English. Various strategies, methods and techniques were developed for teaching English (Burden and Byrd, 2007; Şimşek, 2009; Demirel, 2012; Lang and Evans, 2006; Hengirmen,1993; Marzano, Gaddy and Dean 2000; Şahin, 2013; Ceyhan, 2007). One of these is the approach established by Hutchinson and Waters. They came up with a learning-based approach called "English for Specific Purposes" in 1987. While old theories focused more on the learning needs of a language, Hutchinson and Waters focused on how language learners learnt the language. They researched which stages the language learners underwent until reaching the point where they wished for. According to this theory, language learning needs are examined through two different channels: targeted needs and learning needs. Targeted needs consist of requirements, weaknesses and demands, while learning needs include gender, age, educational background, social and cultural bases. Targeted needs can be divided under three headings:

Needs include the basic knowledge required for a person to achieve his/her targets. For instance, a business person has to possess the grammar and vocabulary knowledge to achieve their main targets such as communicating with the people with whom they are in business with and understanding about the products to be purchased in a catalogue.

Deficiencies can be defined as the difference between the point that a person wants to reach, and their current point. While performing the needs analysis, the difference between the person's current level and the point that he/she wants to reach must be analyzed in detail.

When it comes to demands, needs cannot be mentioned independently from the individuals. Individuals are aware of their targets, the channels through which they want to achieve those targets, their current level and their deficiencies. Such awareness gives rise to demands and is very important (Hutchinson and Waters, 1991, p.55-57).

Development of the learning plan for English for Specific Purposes, which is also expressed as "needs analysis", includes the examination of targets first, followed by the evaluation of grammar properties based on specific purposes. One of the main targets of English for Specific Purposes is for learners to be able to use the language at the targeted points efficiently (Hutchinson and Waters, 1991, p. 12).

A "needs assessment systematic design" must include the language needs, cover targets, expectations and all the related content elements, and the needs analysis must be implemented very carefully in the planning process. This is one of the most prominent elements in the planning process of language teaching. Hutchinson and Waters emphasize the importance of these processes and suggest that they must be taken into account in language planning (Hutchinson and Waters, 1991).

Needs analysis refers to general activities performed on a student group in the program preparation process in order to meet their needs (Iwai, Kondo, Lim, Ray, Shimizu \& Brown, 1999). The appropriateness of teaching programs depends on identification of realistic education needs through scientific means (Taba, 1962, Saylor, Alexander \& Lewis, 1981, Oliva, 1988). Needs analysis is the first step of lesson planning and it provides a validity for all the subsequent lesson design activities. Information on how to organize a lesson is obtained through needs analysis, and the relative theoretical level of out-of-class education needs is identified. This undoubtedly contributes to the provision of a realistic education (Johns, 1991). As the need for education is continuous, its stability also requires continuity (Gupta, 2007). Targets that are consistent with education needs help to define realistic teaching targets (Rogers, Vouters \& Gerard, 1992). Thus, individuals receiving the education are pleased and are able to perform the educational activities to a satisfactory level. Motivation and efficiency also increase together with satisfaction (Bureau, 2008).

In needs analysis studies, careful identification of the current levels and targeted levels of students is extremely important in terms of establishing the activities. Nunan (1988) claims that needs analysis is the starting point of a lesson's subject draft or program design. According to Richard, Platt and Weber (cited by Brown, 2001, p.35), needs analysis is a process that determines the needs of a language or a student or student group, which must be sorted based on the priority of needs. Furthermore, needs analysis is an action and process that covers a comparison between the current level and the desired level, the definition of problems, understanding of behaviors and mechanisms that contribute to the current level, identification of which behaviors and mechanisms need to be changed in order to achieve the desired level, and the development and presentation of solution strategies (Gupta, 2007). In this process, both subjective and objective information is used, such as data obtained from observations, interviews, tests and surveys in needs analyses. With reference to this definition, it must be emphasized that the relevant learners have certain needs and it is required to define and prioritize the language requirements of the student based on both subjective and objective information.

It is very important to design the needs analysis as a process focusing on the needs of different stakeholders such as learners, language schools and employers (Juan, 2014, p. 12). A professionally and clearly designed needs analysis enables efficient language teaching and thus facilitates the achievement of pre-identified targets. Data obtained in a needs analysis process can be used as a criterion for reviewing and reassessing the existing education program.

University students prefer faculties that provide education in a foreign language in order to receive a more effective 
education rather than their mother language. According to placement statistics for undergraduate departments gathered by the Student Selection and Placement Center (OSYM) in Turkey, the scores for admission of faculties that teach in Turkish are lower and therefore the possibility of admission in these departments is higher. However, although it is harder to be admitted in a program in a foreign language, it is thought that students are applying for those departments with the specific aim of learning the foreign language more effectively and using it more efficiently in their academic lives. When the preparatory class English education modules and curriculum are reviewed, it is seen that the English they teach is very distinct from technical English. However, it is believed that students need to focus on technical English in preparatory classes in order to get the most out of and properly understand their field courses taught in English. From this perspective, it is seen that compliance between the English education provided in preparatory classes and the English used in field courses is essential. Considering the above, the target needs of the English education given in preparatory classes must be identified in line with the degree programs. Therefore, the aim of this study is to reveal the language teaching deficiencies of the preparatory education which is given for engineering undergraduate programs that are taught in a foreign language, and to identify the target needs of the program in terms of preparatory education. The needs intended to be identified for this purpose have been addressed as target needs according to the approach specified by Hutchinson and Waters (1991). With this study an attempt was made to find out the needs by determining the requirements and deficiencies in the identification of target needs.

\subsection{Significance of the Study}

Needs analysis is among the primary factors that must be considered when preparing a language plan. If requirements are omitted and available contents, methods and materials are not used while creating a plan, it will not be possible to achieve the desired targets.

This is a qualitative study, with the aim to find how far the students could reflect their gainings out of one-year preparatory language class onto their field courses in the faculty. It was intended to carry out the identification study by making a comparison between the opinions of lecturers that teach preparatory classes in the School of Foreign Languages and the lecturers that teach field courses. Thus it was desired to identify students' current level in their undergraduate field courses. Besides this, the students' perceptions of the topic were compared with the results, and an attempt was made to assess the awareness levels of students on the topic.

The first thing to do when identifying current levels is to find out the primarily preferred methods and which methods are to be applied more often. After obtaining information in accordance with new approaches and techniques that will be revealed based on the researched methods, the second step to be taken is the collection of data in line with this data. The needs identification stage comes after these two stages, and can be more clearly understood once these stages have been carried out. The discrepancy model has been used in this study for the identification of needs. The difference-based approaches is created by examining the differences between the ascertained success and the expected success (Demirel, 2002).

Through this approach, it is aimed to analyze the current level and identify the needs. The difference between the present level and the desired state is examined. Thus, an attempt is made to identify the needs. The requirement is proportional to the gap between the expected competency and the present competency (Duman, 2017).

An assessment method must be used which can ascertain the qualities that must be possessed by the group being addressed, while deciding whether this method is applicable and revealing whether the group has such qualities (Karacaoglu, 2009). Within this context, the differences between the required level and the current level is the subject of this study, in orderto identify the target needs of preparatory classes for undergraduate programs that are taught in a foreign language.

\section{Method}

In this study, which has been designed according to a qualitative research model, the discrepancy model has been used for the identification of needs. The discrepancy model is a philosophy in which needs are seen as differences or inconsistencies between the performance expected from students and what they actually do (Brown, 1995, p. 38). In other words, it is the difference between the present level and needs. Steps followed under the research method are given in Figure 1. 


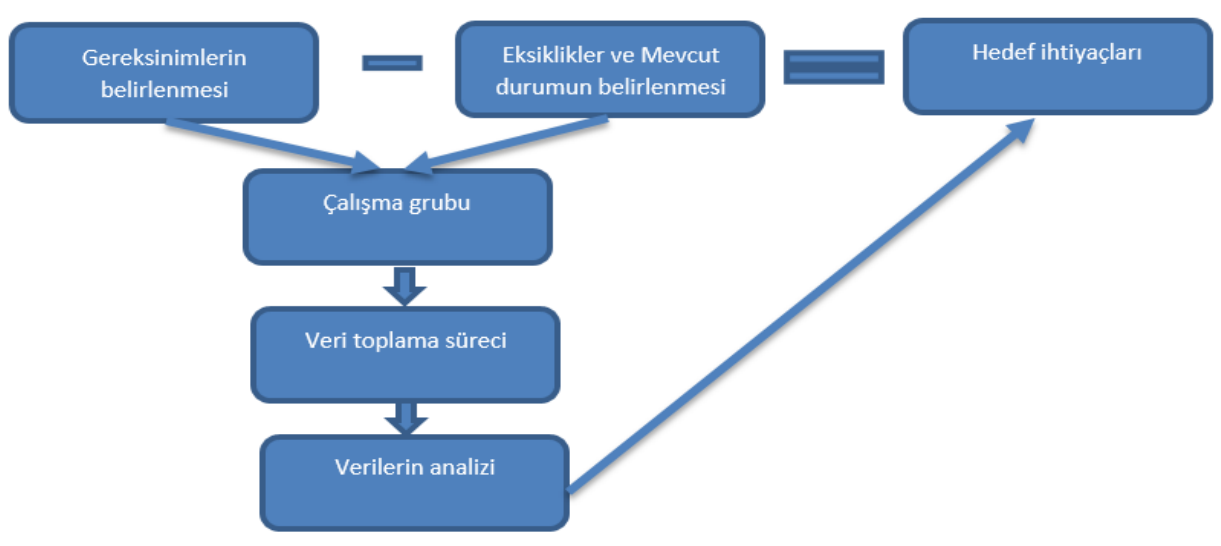

Figure 1. Process followed under the research method

\subsection{Study Group}

At the needs, deficiencies and current level identification stage, the study group was determined using the convenience sampling method.

A total of 19 lecturers were included in the research at the needs identification stage. Among the lecturers, nine worked in Food Engineering, six in Mechanical Engineering, two in Industrial Engineering and another two in Electrical Engineering.

At the deficiencies and current level identification stage, the study group consisted of 23 engineering students who has passed the preparatory class. The students' demographic information is listed in Table 1:

Table 1. Demographic Information of the Students who Stated their Opinions on Preparatory Education

\begin{tabular}{lll}
\hline Department & Year & $\mathrm{N}$ \\
\hline Engineering Physics & 1 & 1 \\
Mechanical Engineering & 1 & 1 \\
Mechanical Engineering & 2 & 2 \\
Mechanical Engineering & 3 & 5 \\
Food Engineering & 2 & 2 \\
Food Engineering & 3 & 4 \\
Food Engineering & Master's Degree & 1 \\
Industrial Engineering & 2 & 1 \\
Industrial Engineering & 3 & 3 \\
Civil Engineering & 3 & 3 \\
Total & & 23 \\
\hline
\end{tabular}

As can be seen in Table 1, the opinions of students from various departments and year groups were consulted, and the maximum participation was obtained from Mechanical Engineering.

Besides the above, 32 preparatory lecturers who work in the School of Foreign Languages participated in the research aimed at revealing the current level of English education given in the preparatory class to prepare students for engineering departments in terms of language teaching.

\subsection{Data Collection Tools and Process}

At the needs identification stage, face-to-face interviews were conducted with six lecturers in the engineering department including three professors, two associate professors and one assistant professor. In these interviews, the participants were asked about what kind of competencies the students must have in terms of listening, speaking, reading, writing and grammar. Based on the responses obtained from the interviews, a 5-point Likert-type scale survey consisting of 34 items was developed and given to 19 lecturers who teach in the engineering departments.

At the deficiencies and current level identification stage, one-to-one online interviews were conducted with 23 engineering students who were asked: "Do you think that the English course you have received in the preparatory class is sufficient for you to receive education in your department? Please explain your answer." Furthermore, the survey that was prepared to reveal the current level was given to 32 lecturers that teach foreign languages in preparatory classes. 


\subsection{Data Analysis}

At the needs identification stage, interviews conducted with lecturers in the Mechanical Engineering Department were transcribed. The data of the survey that was developed based on responses obtained from interviews was analyzed with the SPSS 20.0 statistics package program, and the mean and standard deviation values of each item were calculated.

Table 2. Values used in the interpretation of mean values

\begin{tabular}{ccc}
\hline $\begin{array}{c}\text { Score } \\
\text { interval }\end{array}$ & Rating in Identification of Needs & $\begin{array}{c}\text { Rating in Identification of Deficiencies and Current } \\
\text { State }\end{array}$ \\
\hline $\mathbf{1 . 0 0 - 1 . 8 0}$ & Definitely not important & Definitely not sufficient \\
\hline $\mathbf{1 . 8 1 - 2 . 6 0}$ & Not important & Not sufficient \\
\hline $\mathbf{2 . 6 1 - 3 . 4 0}$ & Partially important & Partially sufficient \\
\hline $\mathbf{3 . 4 1 - 4 . 2 0}$ & Important & Sufficient \\
\hline $\mathbf{4 . 2 1 - 5 . 0 0}$ & Very important & Quite sufficient \\
\hline
\end{tabular}

At the deficiencies and current level identification stage, data obtained from the interviews conducted with students was subject to individual content analysis by two researchers and the consistency of codes was examined after analysis. The concordance percentage was found to be $87.5 \%$ with the concordance percentage formula (Miles and Huberman, 1994). The researchers came to an agreement by discussing the codes where a divergence was seen. As a result, two categories and 18 codes were obtained.

\section{Results}

The data obtained from 23 students in the study groups for the identification of deficiencies and current level was firstly presented. Then it was aimed to reveal the current level of the students' evaluation. The need levels identified by 19 Engineering Department lecturers and the deficiency and current levels identified by 32 English preparatory lecturers were compared by using a survey. The results obtained were presented in a holistic manner, and an attempt was made to identify the target needs of the preparatory classes.

Twenty-three students who started their engineering programs after receiving English courses in the preparatory class were asked if the preparatory class English courses they received were sufficient for them to go on well in field courses education in English. As a result of the content analysis of online reviews made with students, two categories and 18 codes occurred. A table showing the categories and distribution of codes can be found below.

Table 3. Opinions as to Whether the English Education Received in Preparatory Class Is Sufficient for Having Education in Field Courses

\begin{tabular}{ll}
\hline Categories & \multicolumn{1}{c}{ Codes } \\
\hline & Difficulty of understanding the courses in the department (f=3) \\
Little attention paid to grammar in the department \\
Insufficient practice of four skills \\
Great improvement provided by the preparatory class \\
Influence of preparatory class on daily life \\
Inadequacy of preparatory class for those without any prior knowledge \\
Inefficiency of speaking activities in preparatory class \\
Efficiency that is determined by the activeness of the teacher \\
General English taught in preparatory class (f=12) \\
Importance attached to grammar in preparatory class (f=4) \\
Graduation from preparatory class without being equipped \\
Writing activity must be increased (f=2) \\
Speaking activity must be increased (f=4) \\
Requirement to give vocational English courses in preparatory class \\
(f=15)
\end{tabular}


In Table 3, categories are listed under the headings of current level and recommendations. According to the current level category, codes indicating that the education received in preparatory class is not sufficient to have education in field courses. Hence only one student that participated in the interviews stated that the preparatory class education was sufficient, while the other 22 stated the contrary. The most repeated code in the current level category was the "General English taught in preparatory class" code. It is understood that the general English received in preparatory class does not comply with the English structure of the courses received in the field courses in the faculty departments. A second-year student of Food Engineering said the following: "I don't think it is sufficient because I don't believe that the education given in preparatory class complies with the level of language education given in the department." A third-year student of Food Engineering stated: "No, I don't think so because the English we were taught doesn't really comply with the education we receive in the department, it is not even sufficient for the freshman English course we get in the School of Foreign Languages. I think English education must be provided at a sufficient level for the department." A third-year student of Mechanical Engineering answered accordingly: "I don't think that the English courses I took in preparatory class were sufficient for my education in the faculty because the education we receive in preparatory class is based on daily English, but we use academic English in the faculty. This stops us from understanding many lessons and being able to answer questions. The English we learn in preparatory class contributes greatly to our daily life, but is not very useful for our field courses." Students also stated that grammar was given great importance in the preparatory class, while it was not given such importance in the faculty courses.

According to the recommendations category, the resulting three codes concern the improvement of the current level. The majority of the students stated that vocational English must be given in the preparatory class aimed at the field courses. Indeed, a third-year student studying Industrial Engineering said the following: "I don't think the education I received in preparatory class is sufficient for taking courses in the department. But this doesn't necessarily mean that the preparatory class needs to be more strict and difficult. For instance, when I started studying field course in the faculty, I had no technical language foundation in vocational terms. If this technical foundation had at least been given in the compulsory engineering courses, I, or we, wouldn't have had so much trouble in the first year. Therefore I think it is not sufficient." Another third-year student of Industrial Engineering answered accordingly: "I think it wasn't sufficient. Speaking classes in particular were not effective, but they are actually very important. I feel that inadequacy in the presentations we're doing this year. I think there should have been a course such as a freshman course included in the preparatory class." This "freshman course" mentioned by the participant refers to a vocational English course given for 4 hours per week in both semesters of the first year at all engineering departments. This recommendation to add this course to the preparatory class curriculum points to the requirement for vocational English lessons.

The other two codes in the recommendations category are related to speaking and writing activities. Students indicated that more activities focused on these two skills are required in preparatory class. A third-year student studying Civil Engineering said the following: "I don't think it is sufficient because we got a more accelerated version of the education we have received since primary school. There is a huge lack of speaking activities, the course needs to focus more on speaking. We got immersed in grammar, so speaking stayed in the background." This student emphasized that speaking activities were left in the background in preparatory class. A second-year student of Mechanical Engineering answered accordingly: "No, because as our teachers speak Turkish in the class, we fall short in English, besides I think that the number of speaking lessons is very low. I believe that we would do better in English classes by practicing our speaking. Lastly, I think that the English we learn in preparatory class is very basic, and instead we should be learning English that is suitable for our department." The participant also emphasized that both the efficiency of speaking must be increased and vocational English must be taught. The students' focus on three codes in the recommendations category shows that vocational English writing and speaking activities are very effective in enabling the comprehension of the faculty courses.

Considering the responses received in face-to-face interviews conducted with Mechanical Engineering lecturers, the expectation of teachers from the students in terms of listening skills is that they understand the subjects they teach in the class and thus understand the technical terms when they hear them. Their expectation for speaking skills is that students should be able to ask questions in the target language in class. The participants stated that students had self-esteem problems and were unable to ask questions in English due to their fear of making mistakes. In terms of reading skills, the participants emphasized that students must be able to understand the exam questions and technical subjects in coursebooks. For the writing skill, students are expected to respond to exam questions in English, as well as write reports and formal letters in English. And for grammar, some of the participants stated that they had no expectations, while some indicated that students must understand the passive structure, general rules, conjunctions and inverted sentences. According to the opinions of the participants, their expectations from students focus on vocational English and are consistent with the opinions of students.

An analysis of the survey results that were gathered after conducting interviews with Mechanical Engineering lecturers is shown in Table 4. 
Table 4. Mean values of responses given to survey items and the difference between the two values

\begin{tabular}{|c|c|c|c|}
\hline SURVEY ITEMS & $\begin{array}{l}\text { Mean Value for Needs } \\
\qquad\left(\overline{\mathrm{X}}_{1}\right)\end{array}$ & $\begin{array}{c}\text { Mean Value } \\
\text { for } \\
\text { Deficiencies } \\
\text { and Current } \\
\text { Level } \\
\left(\overline{\mathrm{X}}_{2}\right) \\
\end{array}$ & $\begin{array}{l}\text { Difference } \\
\left(\overline{\mathrm{X}}_{1}-\overline{\mathrm{X}}_{2)}\right.\end{array}$ \\
\hline 1. Understanding daily conversations & 3.8421 & 3.8125 & 0.0296 \\
\hline 2. Understanding an academic conversation & 4.2632 & 2.6250 & $1.6382 *$ \\
\hline 3. Understanding accented conversation & 2.6316 & 2.6875 & -0.0559 \\
\hline 4. Understanding conversations that include technical terms & 4.2105 & 2.3750 & $1.8355^{*}$ \\
\hline 5. Speaking with short sentences & 3.8421 & 4.2813 & -0.4392 \\
\hline 6. Speaking with long sentences & 3.2632 & 3.1250 & 0.1382 \\
\hline 7. Expressing individual opinions about a discussion topic for $1-2$ minutes & 4.0000 & 3.3125 & 0.6875 \\
\hline 8. Speaking about a technical topic for 1-2 minutes & 4.3158 & 2.3438 & $1.972 *$ \\
\hline 9. Making a short presentation about a topical subject & 3.8421 & 3.5625 & 0.2796 \\
\hline 10. Making a short presentation about a technical subject & 4.4211 & 2.5313 & $1.8898 *$ \\
\hline 11. Expressing oneself correctly & 4.2105 & 3.6875 & 0,523 \\
\hline 12. Asking questions related to the subject of a lesson & 4.4211 & 3.7813 & 0.6698 \\
\hline 13. Asking questions using specialized terms & 4.5263 & 2.4688 & 2.0575 \\
\hline 14. Understanding short sentences when reading & 4.2632 & 4.3125 & -0.0493 \\
\hline 15. Understanding long sentences when reading & 4.0000 & 3.4375 & 0.5625 \\
\hline 16. Understanding paragraphs on topical subjects when reading & 3.6842 & 3.9063 & -0.2221 \\
\hline 17. Understanding paragraphs on technical subjects when reading & 4.5263 & 2.6563 & $1.87 *$ \\
\hline 18. Understanding a long text on topical subjects when reading & 3.7368 & 3.6563 & 0.0805 \\
\hline 19. Understanding a long text on technical subjects when reading & 4.4737 & 2.4375 & $2.0362 *$ \\
\hline 20. Overall understanding of what is read & 4.1579 & 4.0000 & 0.1579 \\
\hline 21. Understanding exam questions & 4.7368 & 4.2188 & 0.518 \\
\hline 22. Understanding case questions & 4.4211 & 3.9375 & 0.4836 \\
\hline 23. Writing short sentences & 4.3158 & 4.3125 & 0.0033 \\
\hline 24. Writing long sentences & 4.0000 & 3.4063 & 0.5937 \\
\hline 25. Writing a paragraph that expresses one's opinions on a discussion topic & 3.8421 & 3.8438 & -0.0017 \\
\hline 26. Writing a paragraph on a technical subject & 4.3158 & 2.5625 & $1.7533 *$ \\
\hline 27. Writing a long text about a topical subject & 3.5263 & 3.3125 & 0.2138 \\
\hline 28. Writing a report on a technical subject & 4.4737 & 2.2500 & $2.2237 *$ \\
\hline 29. Writing an article on a technical subject & 3.9474 & 2.0313 & $1.9161 *$ \\
\hline 30. Writing a formal letter & 3.6316 & 3.0000 & 0.6316 \\
\hline 31. Writing a resume & 4.0526 & 3.5938 & 0.4588 \\
\hline 32. Describing a graph in writing & 4.2632 & 2.8125 & $1.4507 *$ \\
\hline 33. Converting a written text into a graph & 4.2105 & 2.6563 & $1.5542 *$ \\
\hline 34. Writing exam responses in English & 4.6316 & 3.9688 & 0.6628 \\
\hline
\end{tabular}

According to Table 4, there is a significant difference between the importance level of 11 skills and the current level. For instance, while Engineering Department lecturers in the study stated that the "Understanding an academic conversation" skill is very important $(\overline{\mathrm{X}}=4.26)$, preparatory lecturers emphasize that the relevant skill is not sufficiently provided in preparatory class $(\overline{\mathrm{X}}=2.63)$. Therefore while the relevant item is emphasized as important in terms of engineering education, it is seen that students cannot acquire this skill sufficiently in preparatory classes. From this perspective, it may be thought that the skill of understanding an academic conversation is a skill that must be given to students in the available preparatory classes. It is also seen that there is a significant difference between the importance level and current level in the skills of "Understanding conversations that include technical terms" $\left(\overline{\mathrm{X}}_{1}=4.21 ; \overline{\mathrm{X}}_{2}=2.38\right)$; "Speaking about a technical subject for 1-2 minutes" $\left(\overline{\mathrm{X}}_{1}=4.32 ; \overline{\mathrm{X}}_{2}=2.34\right)$; "Making a short presentation on a technical subject" $\left(\overline{\mathrm{X}}_{1}=4.42 ; \overline{\mathrm{X}}_{2}=2.53\right)$; "Understanding paragraphs on technical subjects when reading" ( $\left.\overline{\mathrm{X}}_{1}=4.53 ; \overline{\mathrm{X}}_{2}=2.66\right)$; "Writing a paragraph about a technical subject" $\left(\overline{\mathrm{X}}_{1}=4.32 ; \overline{\mathrm{X}}_{2}=2.56\right)$; "Writing a report on a technical subject" $\left(\overline{\mathrm{X}}_{1}=4.47 ; \overline{\mathrm{X}}_{2}=2.25\right)$; "Writing an article about a technical subject" $\left(\overline{\mathrm{X}}_{1}=3.95 ; \overline{\mathrm{X}}_{2}=2.03\right)$; "Describing a graph in writing" $\left(\overline{\mathrm{X}}_{1}=4.26 ; \overline{\mathrm{X}}_{2}=2.81\right)$ and "Converting a written text into a graph" $\left(\overline{\mathrm{X}}_{1}=4.21 ; \overline{\mathrm{X}}_{2}=2.66\right)$. Therefore providing the relevant skills is thought to be a need. It is seen that these skills are focused on vocational English. The obtained findings are consistent with the opinions of students, as the students also mentioned similar issues in online interviews. Besides the above, these findings also support the interviews conducted with Mechanical Engineering lecturers. This shows that the expectations of lecturers are similar regardless of the department, because the survey was given to lecturers from different departments.

In brief, both student opinions and opinions of faculty lecturers focus on the issue that technical and vocational English must be taught in preparatory class. 


\section{Discussion}

The majority of the students who participated in the study and field courses' lecturers agree that the technical and vocational English taught in preparatory classes is insufficient and that no steps have been taken for this problem. They claim that the focus in preparatory classes is on grammar rather than the acquirement of skills that will be more useful for them, such as speaking skills and the ability to use technical terms. According to Aydın (2000), grammar is not a purpose but a tool in language education and learning, however this has always been misunderstood and grammar rules have been taught instead of the language itself. The purpose has become the tool, and students have been raised who know the rules of a language but cannot speak that language or understand what they read.

According to both the students and field course lecturers, with the curriculum of English preparatory classes that is currently in use, the needed language skills cannot be provided in a balanced way and students cannot be supported well to improve such skills. In a study by Gomleksiz (1993) called "Yükseköğretimde Yabancı Dil Öğretimi ve Sorunları" (Foreign Language Teaching in Higher Education and Problems), the fact that lecturers focus on grammar in the lessons and ignore basic language skills was one of the problems cited. According to the responses taken from students on English teaching in higher education, such a problem is still seen at present 25 years later.

In Gokdemir's research conducted to identify the problems faced by students that had studied or were studying in preparatory class while learning English $(2003,2005)$, it was seen that too much importance was attached to providing theoretical knowledge, however insufficient care was given to practice, student attendance could not be achieved, lessons were teacher-oriented, and the physical environment and the applied program were not very appropriate. The above result is similar to the result of this study because students who have started their filed course studies after preparatory class education also emphasized that these lessons fall far behind in speaking skills in terms of practice, focus too much on grammar, and have therefore left them with difficulties in expressing themselves and making project presentations. In his study called "The Turkish Higher Education System in Light of International Improvements: Main Tendencies, Problems, Discrepancies and Recommendations", Senses (2007) initiated a new discussion about foreign language education and emphasized that students who receive foreign language education in preparatory classes at university must start their undergraduate studies with a sufficient amount of foreign language knowledge.

In faculties, a common compulsory English course is given in two semesters, divided up as English-I and English-II, for four hours a week. According to the responses of the students, an opinion arises that the content of these courses must be presented in the preparatory class curriculum. Because students indicate that they get overwhelmed with technical terms when they start field courses and have serious difficulties in understanding them. As engineering students will always be engaged with these terms due to their fields of expertise during both their university and occupational life, the English-I and English-II courses they receive in the department after completing their preparatory class education do not meet their expectations and needs.

\section{Conclusion and Suggestions}

The opinions of students, preparatory lecturers and lecturers gathered in the study have been individually reviewed. According to these opinions, the preparatory class provides students with general English skills. The English curriculum of the preparatory class ensures that students acquire these skills. It was seen that general English classes taken throughout the year focused on grammar and that students were provided with speaking and writing skills for general subjects at a general level. However, according to the views of students and lecturers who lecture in field courses, the general levels of English achieved are not sufficient field courses. The fact that students do not learn the technical terms related to their fields in the preparatory class and come across them for the first time in the faculty courses, or have only just touched upon them in freshman courses, causes problems in lessons, presentations and reports where these technical terms are commonly used, as well as the areas of comprehension, interpretation, and responding and reporting in exams. Students and lecturers experience problems in the understanding and presentation of technical texts.

It is believed that reviewing and combining the Preparatory Class English Curriculum and the first year Freshman English Course Curriculum will provide a substantial solution to these problems. Thus knowledge of the technical terms related to the field courses will be acquired earlier, and accordingly, students will get early experience of the topics related to their subjects of study. They will be able to understand and interpret the technical texts as well as write technical articles. The early solution of this problem will enable the preparatory lecturers to provide timely feedback to problems of understanding and expression that are faced by the students who are learning English, and the students will be able to gain technical English skills as well as general English skills. This will have an indirect positive effect on the success of students at undergraduate level, because students will now be engaged with gaining English skills in their own fields of study instead of simply learning English.

Furthermore, speaking activities must be increased both in preparatory class and freshman courses, and materials required for the students to speak fluently and correctly in formal and informal environments must be designed. In this way, 
students that overcome their self-confidence problem in speaking lessons during the preparatory class and can improve high-level speaking skills when they are at freshman level. Students must be reminded of how important the speaking skill is for long and short-term career plans and that the most reliable resource for best improving this skill is the program taught at the School of Foreign Languages, as well as the preparatory lecturers who teach the program. For all these purposes, preparatory lecturers teaching the preparatory English classes and lecturers teaching field courses at the faculty can collaborate, and the Preparatory Class English Curriculum can be updated in cooperation with curriculum development specialists.

\section{References}

Aydın, M. Z. (2000). Arapçayı nasıl öğretelim?[How to teach Arabic?] İstanbul: MEB

Brown, J. D. (1995). The Elements of Language Curriculum: a Systematic Approach to Programme Development. Boston: Heinle and Heinle Publishers, 20 Park Plaza, Boston, MA 02116.

Brown, J. D. (2001). Using surveys in language programs. Cambridge: Cambridge University Press.

Burden, P. R., \& Byrd, D. M. (2007). Methods For Effective Teaching (4.Baskı). Pearson

Bureau, S. (2008). Analyse des Besoins de Formation. www.did.coop/documents/I-009.pdf (14.12.2009).

Ceyhan, E. (2007) Yabancı Dil Öğretimi Teknolojisi.[Technologies for Teaching Foreign Languages] İstanbul: Morpa Kültür Yayınları

Demirel, Ö. (2002). Eğitimde Program Geliştirme Kuramdan Uygulamaya.[From Theory to Practise: Developing Curriculum in Education] 20. Bask1, Pegem A Yayıncılık. Ankara.

Demirel, Ö. (2012). Yabancı Dil Öğrenimi..[Foreign Language Learning] (7.Bask1). Ankara: Pegem Akademi

Duman, B. (2017). Eğitimde Çağdaş Yaklaşımlar..[Contemporary Approaches in Education] Pegem Atıf İndeksi, 367-385. https://doi.org/10.14527/9786053189886.07

Gokdemir, C. V. (2003). Üniversitelerde Ingilizce Hazirlik Programina Devam Eden Öğrencilerin Ingilizce Derslerinde Karşilaştiklari Sorunlar.[The Problems The Undergraduate Students Encounter with While Learning English] (Yayımlanmamış doktora tezi). Dokuz Eylül Üniversitesi, İzmir.

Gokdemir, C. V. (2005). Üniversitelerimizde Verilen Yabanci Dil Öğretimindeki Başari Durumumuz,.[Our Success Level in Teaching Foreign Languages in Our Universities] Atatürk Üniversitesi Sosyal Bilimler Enstitüsü Dergisi, 6(2), 251-264.

Gomleksiz, M. N. (1993). Yükseköğretimde Yabanci Dil Öğretimi Ve Sorunlari (Firat Üniversitesi Örneği)..[Foreign Language Teaching at Universtiy and Problems] (Yayımlanmamış yüksek lisans tezi). Fırat Üniversitesi, Elazığ.

Gupta, K. (2007). A Practical Guide To Needs Assessment (2nd ed.). San Francisco, CA: John Wiley \& Sons, Inc.

Hengirmen, M. (1993). Yabancı Dil Öğretim Yöntemleri. .[Foreign Language Teaching Methods]Ankara: Engin Yayın Evi

Hutchinsons, T., \& Waters A. (1991). English For Specific Purposes, Cambridge University Press: Great Britain.

Hutchinsons, T., \& Waters, A. (1987). English For Specific Purposes: A Learning-Centered Approach. Cambridge: Cambridge University Press. https://doi.org/10.1017/CBO9780511733031

Iwai, T., Kondo, K., Lim, D., Ray, G., Shimizu, H., \& Brown, J. (1999). Japanese Language Needs Analysis. Honolulu: University of Hawai, Second Language Teaching and Curriculum Center.

Johns, A. (1991). English for specific purposes: its history and contribution. In CelceMurcia, M. (Ed.), Teaching English as a Second or Foreign Language. Boston: Heinle \& Heinle, 67-77.

Juan, L. (2014). Literature Review of the Classifications of "Needs" in Needs Analysis Theory, International Journal of Education \& Literacy Studies, 2(3), 12-16.

Karacaoglu, Ö. C. (2009). İhtiyaç Analizi ve Delphi Tekniği: Öğretmenlerin Eğitim İhtiyacını Belirleme Örneği.[The Needs Analyses and Delphi: An Example for Identifiying the Teachers' Learning Needs]. Adnan Menderes Üniversitesi. Aydın.

Lang, H. R., \& Evans, D. N. (2006). Models, Strategies and Methods For Effective Teaching. Pearson

Marzano, R. J., Gaddy, B. B., \& Dean,C. (2000). What Works In Classroom Instruction. Aurora: McREL

Miles, M, B., \& Huberman, A. M. (1994). Qualitative data analysi s: An expanded Sourcebook. (2 nd ed). Thousand Oaks, CA: Sage. 
Nunan, D. (1988). Syllabus design. Oxford:Oxford University Press.

Oliva, P. F. (1988). Developing the curriculum. USA: Scott, Foresman and Company.

Rogers, X., Vouters, P., \& Gerard, F. M. (1992). Formation et Technologies. Revue Europeenne des Professionnels de la Formation, 1(2-3), 32-42.

Sahin, Y. (2013). Farklı Boyutlarıyla Yabancı Dil Öğrenimi ve Öğretimi.[Foreign Languages Learning and Teaching from Different Perspectives]. Konya: Eğitim Yayınevi

Saylor, J. G., Alexander, M., \& Lewis, A. J. (1981). Curriculum planning for better learning. New York: Holt, Rinehart and Winston.

Senses, F. (2007). Uluslararası Gelişmeler Işı̆̆ında Türkiye Yükseköğretim Sistemi: Temel Eğilimler, Sorunlar, Çelişkiler ve Öneriler.[The Turkish Higher Education in the Light of International Developments: Main Tendencies, Problems, Conflicts and Proposal], ERC Working Papers in Economics, 1-31.

Simsek, A. (2009). Öğretim Tasarımı.[Design for Teaching]. Nobel Yayıncılık

Taba, H. (1962). Curriculum development: Theory and practice. New York: Harcourt, Brace \& World Inc.

\section{Copyrights}

Copyright for this article is retained by the author(s), with first publication rights granted to the journal.

This is an open-access article distributed under the terms and conditions of the Creative Commons Attribution license which permits unrestricted use, distribution, and reproduction in any medium, provided the original work is properly cited. 